\section{Commentary: In search of the ideal right ventricle-to-pulmonary artery conduit: Is perfect the enemy of good, or will it foster excellence?}

\section{Minoo N. Kavarana, MD}

Rastelli and colleagues ${ }^{1}$ were the first to report the use of a nonvalved pericardial tube in a child with pulmonary atresia. The following year, Ross reported the use of an aortic homograft (AH) as a right ventricle-to-pulmonary artery (RV-PA) conduit. ${ }^{2}$ Homografts were harvested within 48 hours of death, treated with antibiotics, and stored at $4^{\circ} \mathrm{C}$ for up to 4 weeks. Early techniques used to preserve homografts involved irradiation or freeze drying, which resulted in severe collagen damage of the leaflets with subsequent degeneration. Older techniques were abandoned to make way for cryopreservation with controlled freezing to $196^{\circ} \mathrm{C}$ with liquid nitrogen, which allowed larger-scale harvest and storage ability for longer periods. Despite issues with long-term durability secondary to cell viability, pulmonary homografts (PHs) remain the gold standard against which newer conduits are compared. ${ }^{3}$ Antibodies develop against donor human leukocyte antigens and have been linked to calcification, degeneration, and valve failure, which in one study seemed less evident when compared with decellularized homografts. ${ }^{4}$

The bovine jugular vein (BJV) graft was introduced in 1999 and provided a reliable alternative to homografts with the advantage of being easily available at a variety of sizes $(12-22 \mathrm{~mm})$. The early results were promising, with durability comparable with $\mathrm{PH}^{5}$ Unfortunately, a

From the Section of Pediatric Cardiothoracic Surgery, Medical University of South Carolina, Charleston, SC.

Disclosures: The author reported no conflicts of interest.

The Journal policy requires editors and reviewers to disclose conflicts of interest and to decline handling or reviewing manuscripts for which they may have a conflict of interest. The editors and reviewers of this article have no conflicts of interest.

Received for publication Sept 6, 2020; revisions received Sept 6, 2020; accepted for publication Sept 24, 2020; available ahead of print Oct 22, 2020.

Address for reprints: Minoo N. Kavarana, MD, Section of Pediatric Cardiothoracic Surgery, 10 McClennon Banks Dr, SJCH 2190/ MSC 918r, Charleston, SC 29425 (E-mail: kavarana@musc.edu).

JTCVS Open 2020;4:66-7

2666-2736

Copyright $(2020$ The Authors. Published by Elsevier Inc. on behalf of The American Association for Thoracic Surgery. This is an open access article under the CC BY-NCND license (http://creativecommons.org/licenses/by-nc-nd/4.0/).

https://doi.org/10.1016/j.xjon.2020.09.005

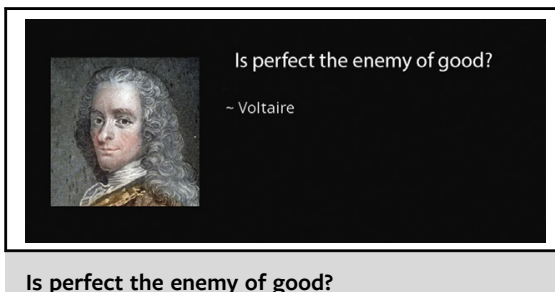

Is perfect the enemy of good?

CENTRAL MESSAGE

The cryopreserved femoral vein

graft as a right ventricle-to-

pulmonary artery conduit per-

forms as well as the pulmonary

homograft in the short term.

well-conducted study demonstrated a significant incidence of endocarditis as high as $10 \%$ at 7.5 years. $^{6}$

A multicenter prospective study demonstrated that RVPA conduits had a significant reoperation rate. Although there was no significant difference in durability among different conduit materials ( $\mathrm{PH}, \mathrm{AH}$, and $\mathrm{BJV}$ ), the authors found that small conduit size was associated with failure. The dearth of available homografts in Japan stimulated surgeons to develop hand-made expanded polytetrafluoroethylene conduits, which at medium-term follow up have demonstrated excellent durability. ${ }^{8}$

Sinha and colleagues ${ }^{9}$ compared cryopreserved femoral vein homograft $(\mathrm{FVH})$ for RV-PA conduit replacement with $\mathrm{PH}$ and $\mathrm{AH}$. They found that the FVH conduit performance was similar to $\mathrm{PH}$ and superior to $\mathrm{AH}$. Comparable rates of conduit stenosis were observed with FVH with greater rates of insufficiency. FVHs were available in 10to $15-\mathrm{mm}$ sizes, which are advantageous in neonates and infants. The excess length at either end of the valve allows more versatility. The lower cost with the potential to acquire multiple conduits from a single vein make this an economical option. FVHs are thin walled with favorable handling characteristics in comparison with the BJV graft and expanded polytetrafluoroethylene conduits, which are thicker walled, making the distal anastomosis in neonates more challenging. The weaknesses of the study are the short follow-up and greater incidence of conduit insufficiency, which is concerning for neonates and infants with pulmonary hypertension.

In conclusion, although $\mathrm{FVH}$ is an attractive conduit alternative, longer-term follow-up to evaluate valve function and conduit durability is essential. Although the FVH may become an important tool in the surgeon's 
armamentarium, the search for the ideal conduit will continue to promote excellence.

\section{References}

1. Rastelli GC, Ongley PA, Davis GD, Kirklin JW. Surgical repair for pulmonary valve atresia with coronary-pulmonary artery fistula: report of a case. Mayo Clin Proc. 1965;40:421-7.

2. Ross DN, Somerville J. Correction of pulmonary atresia with a homograft aortic valve. Lancet. 1996;2:1446-7.

3. Allen MD, Shoji Y, Fujimura Y, Gordon D, Thomas R, Brockbank KG, et al Growth and cell viability of aortic versus pulmonic homografts in the systemic circulation. Circulation. 1991;84(5 suppl):III94-9.

4. Konuma T, Devaney EJ, Bove EL, Gelehrter S, Hirsch JC, Tavakkol Z, et al. Performance of CryoValve SG decellularized pulmonary allografts compared with standard cryopreserved allografts. Ann Thorac Surg. 2009;88:849-54.
5. Prior N, Alphonso N, Arnold P, Peart I, Thorburn K, Venugopal P, et al. Bovine jugular vein valved conduit: up to 10 years follow-up. J Thorac Cardiovasc Surg. 2011;141:983-7.

6. Beckerman Z, De Leon LE, Rodrigo ZV, Mery CM, Fraser CD. High incidence of late infective endocarditis in bovine jugular vein valved conduits. J Thorac Cardiovasc Surg. 2018;156:728-34.

7. Karamlou T, Blackstone EH, Hawkins JA, Williams WG, McCrindle BW. Can pulmonary conduit dysfunction and failure be reduced in infants and children less than age 2 years at initial implantation? J Thorac Cardiovasc Surg. 2006; 132:829-38.

8. Miyazaki T, Yamagishi M, Maeda Y, Yamamoto Y, Taniguchi S, Sasaki Y, et al. Expanded polytetrafluoroethylene conduits and patches with bulging sinuses and fan-shaped valves in right ventricular outflow tract reconstruction: multicenter study in Japan. J Thorac Cardiovasc Surg. 2011;142:1122-9.

9. Sinha L, Mota L, Ozturk M, Staffa SJ, Zurakowski D, Jonas RA, et al. Cryopreserved valved femoral vein homografts for right ventricular outflow tract reconstruction in infants. J Thorac Cardiovasc Surg Open. 2020;4:58-65. 